\title{
SCHISTOSOMIASIS
}

\section{IN THE NORTHERN STATE \\ OF ESPÍRITO SANTO, BRAZIL}

Renan Florindo Amorim ${ }^{1}$, Janaina dos Santos Maciel', Fabiana Mendonça Ambrozim $^{l}$, Clarissa Pereira de Almeidal, Naizillah de Oliveira Albuquerque ${ }^{l}$, Damila Andrion Venturin ${ }^{1}$, Vanessa Ghidetti Alvarenga Telles', Dayane Hoffmam Crause $^{l}$, Aparecida Rios Soares ${ }^{l}$ and Marco Antônio Andrade de Souza ${ }^{l}$.

\begin{abstract}
It is estimated that Schistosoma mansoni is present in 19 Brazilian states and one of the factors responsible for the spread of schistosomiasis is the migration of individuals from endemic areas, particularly from northeastern Brazil. In the municipality of Conceição da Barra, northern state of Espírito Santo, the present study aimed to evaluate the occurrence of schistosomiasis among sugarcane cutting workers in the alcohol industry, who migrated from the northeastern region of the country. For the diagnosis of intestinal parasites, spontaneous sedimentation and Kato-Katz techniques were used. Of the 287 individuals analyzed, 45 (15.7\%), from the states of Alagoas, Pernambuco and Bahia, were positive for S. mansoni. Of the total positive individuals, 38 (84.4\%) were from the state of Alagoas, 6 (13.3\%) from Pernambuco and $1(2.2 \%)$ from Bahia. The results indicate the possibility of schistosomiasis expansion in the northern state of Espírito Santo.
\end{abstract}

KEYWORDS: Schistosoma mansoni; Conceição da Barra; migrants; transmission.

\section{RESUMO}

Esquistossomose no norte do estado do Espírito Santo, Brasil.

Estima-se que o Schistosoma mansoni esteja presente em 19 estados brasileiros e um dos fatores responsáveis pela expansão da esquistossomose é a migração de indivíduos de áreas endêmicas,

1 Laboratório de Análises Clínicas, Departamento de Ciências da Saúde, Centro Universitário Norte do Espírito Santo, Universidade Federal do Espírito Santo, Espírito Santo, Brasil.

2 Drogasil. Rua Eugenílio Ramos 329, 29060-130 Vitória, Espírito Santo, Brasil.

Corresponding author: Dr. Marco Antônio Andrade de Souza, Departamento de Ciências da Saúde, Centro Universitário Norte do Espírito Santo, Universidade Federal do Espírito Santo. Rodovia BR 101 Norte, Km 60, Litorâneo, CEP: 29932-540, São Mateus, ES, Brasil. Email: marco.souza@ ufes.br

Received for publication: 21/7/2013. Reviewed: 20/3/2014. Accepted: 19/5/2014. 
principalmente do Nordeste do país. O presente estudo teve por objetivo avaliar a ocorrência da esquistossomose entre trabalhadores, migrantes da Região Nordeste do país, que atuavam em Conceição da Barra, norte do Espírito Santo, no corte da cana-de-açúcar para uma indústria de produção de álcool. Para a determinação dos parasitos intestinais, foram utilizadas as técnicas de sedimentação espontânea e Kato-Katz. Dos 287 indivíduos analisados, 45 (15,7\%), provenientes dos estados de Alagoas, Pernambuco e Bahia, estavam positivos para S. mansoni. Do total de positivos, $38(84,4 \%)$ eram provenientes do estado de Alagoas, 6 (13,3\%) do estado de Pernambuco e apenas $1(2,2 \%)$ do estado da Bahia. Os resultados indicam a possibilidade de expansão da esquistossomose na região norte do Espírito Santo.

DESCRITORES: Schistosoma mansoni; Conceição da Barra; migrantes; transmissão.

\section{INTRODUCTION}

The human ability to promote health is notable, either through achievements in the field of medicine or improving the material conditions of humanity. However, some old diseases still persist in the 21st century (29) and schistosomiasis is one of them.

Also known, in Brazil, as "barriga d'água or xistose", it is a parasitic disease caused by a digenetic trematode Schistosoma mansoni $(13,24)$, whose most important manifestations are liver alterations related to the fibrosis stage caused by the parasite (32).

It is a serious health problem (12), especially in developing countries, where there is an imbalance between wealth distribution, health care, socioeconomic, cultural and health conditions, which are factors that contribute to the spread and maintenance of the life cycle of parasites (33).

Schistosomiasis becomes an even greater problem when associated with malnutrition, afflicting populations from a large geographical area of northeastern and southeastern Brazil, 4 to 10\% of them in the most productive age of life(18).

In Brazil, it is estimated that the number of $S$. mansoni carriers varies between 2,500,000 and 8,000,000 and that the parasite is present in 19 states and the Federal District, covering an endemic area ranging from Maranhão down to Espírito Santo and Minas Gerais, with foci of transmission in other states $(1,5,21$, 25). However, knowledge of the epidemiological behavior of this disease is limited (13), with the highest prevalence being observed, currently, in municipalities from the states of Alagoas, Pernambuco, Sergipe, Bahia, Paraíba and Minas Gerais (22).

In Alagoas state, according to data from the Schistosomiasis Control Program, $9.9 \%$ of the population evaluated in the last ten years was infected with $S$. mansoni (27). In the states of Pernambuco and Bahia, prevalence of the disease in 2011 was $5.3 \%$ and $3.3 \%$, respectively (27). This situation is worrying, both because of the health problems caused by the parasite and the possibility of disease spread, due to the thousands of northeastern workers shifting their regions of origin in search of work, to different regions of the country, in particular to the state of Espirito Santo, where the number of individuals infected by the parasite is more than $200,000(13,27)$. 
In fact, due to the intense rural exodus, large population densities have to survive in small spaces, with inadequate and poor sanitation, which contributes to the formation of new foci of disease transmission. This situation is observed by many authors that associate the phenomenon of urbanization of schistosomiasis with socioeconomic and behavioral factors $(2,23,30)$.

In this respect, the performance of a parasitological survey with sugarcane cutters that migrate every year from the northeastern states of Brazil to the state of Espírito Santo, especially to the municipality of Conceição da Barra, a leading alcohol production center, allowed for the investigation of schistosomiasis spread in the region.

\section{METHODS}

Study Area

Located in the mid-region of the northern coast of Espírito Santo (Figure 1), the municipality of Conceição da Barra (S18 35' 24.6", W039 43' 45.2') is 256 $\mathrm{km}$ away from the state capital Vitória. It has an area of approximately $1,188 \mathrm{~km}^{2}$ and estimated population for the year 2010, by the Brazilian Institute of Geography and Statistics (IBGE) of 28,745 inhabitants (11). The poverty rate is high and sanitation is inadequate both in urban and rural areas.

Most of its economy is based on the provision of services, followed by industry and agriculture and cattle raising. The city also has two large alcohol distilleries, and it is estimated that 600,000 tons of sugar cane were produced in 2010 , generating direct and indirect employment to workers coming from various regions, especially from the northeastern region of the country(11).

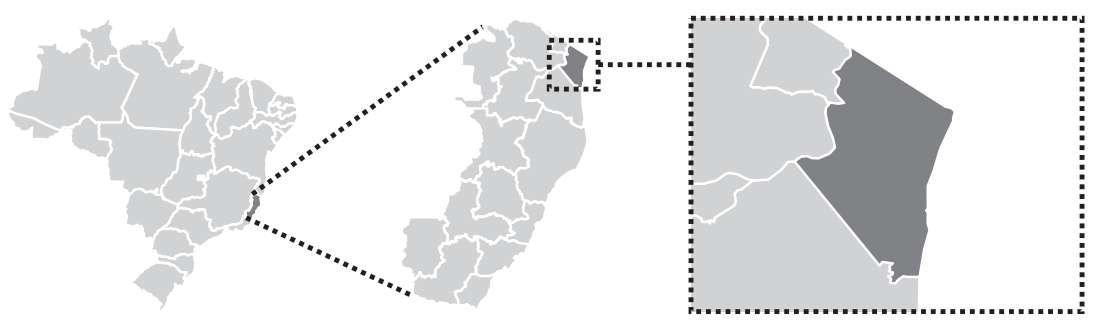

Figure 1. Espírito Santo Northern state: Conceição da Barra. Source: Souza \& Melo, 2012.

Study design

This study was carried out with 287 workers, from a total of 400, at an alcohol producing plant in Conceição da Barra, northern state of Espírito Santo who agreed to participate. This is a descriptive study, conducted between July and December 2011. All workers were from northeastern states of Brazil. 
The collectors began work at the beginning of each week and the samples collected were sent to the Laboratório de Análises Clínicas of the Centro Universitário Norte do Espírito Santo of the Universidade Federal do Espírito Santo (CEUNES/UFES). One parasitological stool sample was collected from each worker and the samples were kept in isothermal boxes containing dry ice and stored until processing in the laboratory by spontaneous sedimentation and Kato-Katz methods $(10,14)$. Three Kato-Katz slides were prepared for each sample.

It is noteworthy that all workers in the study were males, aged from 18 to 59 years, from the northeastern states of Brazil.

Ethics Research Committee

The project began after its approval by the Ethics Research Committee of the Centro Universitário Norte do Espírito Santo of the Universidade Federal do Espírito Santo (No. 070/2011) and individuals who participated in the survey signed the informed consent form. Once diagnosed, positive cases of parasitic infectionwere referred for medical treatment.

\section{RESULTS}

Among the 287 workers who participated in this study, from a total of 400 at the plant, $45(15.7 \%)$ were infected with $S$. mansoni. Of these, $38(84.4 \%)$ were from the state of Alagoas, $6(13.3 \%)$ from the state of Pernambuco and $1(2.2 \%)$ from the state of Bahia. Workers from other northeastern states of Brazil were also evaluated, but none was positive for $S$. mansoni (Table 1).

Table 1. Number of positive and negative individuals and city of origin of sugarcane cutting workers parasitized by Schistosoma mansoni in northern Espírito Santo, Brazil, 2011.

\begin{tabular}{cccc}
\hline Positive individuals & Negative individuals & City of origin & Brazil state \\
\hline 11 & 68 & Maragogi & $\mathrm{AL}$ \\
\hline 11 & 56 & Branquinha & $\mathrm{AL}$ \\
\hline 7 & 43 & Santana do Mundaú & $\mathrm{AL}$ \\
\hline 6 & 35 & União dos Palmares & $\mathrm{AL}$ \\
\hline 1 & 8 & Murici & $\mathrm{AL}$ \\
\hline 1 & 6 & Ibateguara & $\mathrm{AL}$ \\
\hline 1 & 4 & Campestre & $\mathrm{AL}$ \\
\hline 1 & 7 & Lagoa Real & $\mathrm{BA}$ \\
\hline 3 & 4 & Tabira & PE \\
\hline 2 & 3 & Barreiros & PE \\
\hline 1 & 2 & Caruaru & PE \\
\hline 0 & 4 & Lagoa Real & $\mathrm{BA}$ \\
\hline 0 & 2 & Estância & SE \\
\hline Total $(45)$ & Total $(242)$ & &
\end{tabular}


The Kato-Katz method allowed the identification of 42 positive samples whereas 15 positive samples were determined by the sedimentation method. For this method other parasites were identified. Among positive samples, the most common protozoa were Entamoeba coli (50.5\%), Entamoeba histolyticalE. dispar (20.7\%), G. lamblia (9.1\%), Iodamoeba butschlii (3.83\%) and Endolimax nana (2.87\%). Regarding helminths, the most common were hookworm (23.9\%), A. lumbricoides (9.09\%), S. mansoni (7.2\%), Trichuris trichiura (4.3\%), Hymenolepis nana (3.8\%) and Enterobius vermicularis (1.4\%).

Once the number of infected individuals was established, the number of $S$. mansoni eggs per gram of feces per individual was determined, with values ranging from 24 to 864 epg. Of all infected individuals, 32 (76.2\%) had low parasite load (up to $100 \mathrm{epg}$ ), 8 (19.1\%) had intermediate parasite load ( $>100$ and $<400 \mathrm{epg}$ ) and 2 (4.8\%) had high parasite load (above 400 epg) $(22,3)$ (Table 2).

Table 2. Number of Schistosoma mansoni eggs per gram (epg) per sugarcane cutting workers and percentage of infected individuals by age in northern Espírito Santo, Brazil, 2011.

\begin{tabular}{ll}
\hline \multicolumn{2}{c}{ Number of infected workers epg (feces) } \\
\hline 1 & 864 \\
\hline 1 & 720 \\
\hline 1 & 312 \\
\hline 1 & 300 \\
\hline 1 & 216 \\
\hline 3 & 168 \\
\hline 1 & 144 \\
\hline 1 & 124 \\
\hline 22 & 72 \\
\hline
\end{tabular}

Total (42)

\begin{tabular}{|c|c|}
\hline Age group in years & Number and percentage of infected individuals \\
\hline $18-28$ & $12(28.6 \%)$ \\
\hline 29-39 & $19(45.2 \%)$ \\
\hline $40-50$ & $11(26.2 \%)$ \\
\hline $51-59$ & 0 \\
\hline Total & $42(100.0 \%)$ \\
\hline
\end{tabular}

Regarding the age of the study participants (Figure 2), this ranged from 18 to 59 years, and those aged from 29 to 39 years showed the highest number of individuals parasitized by $S$. mansoni when both parasitological techniques were considered (20 infected individuals). 


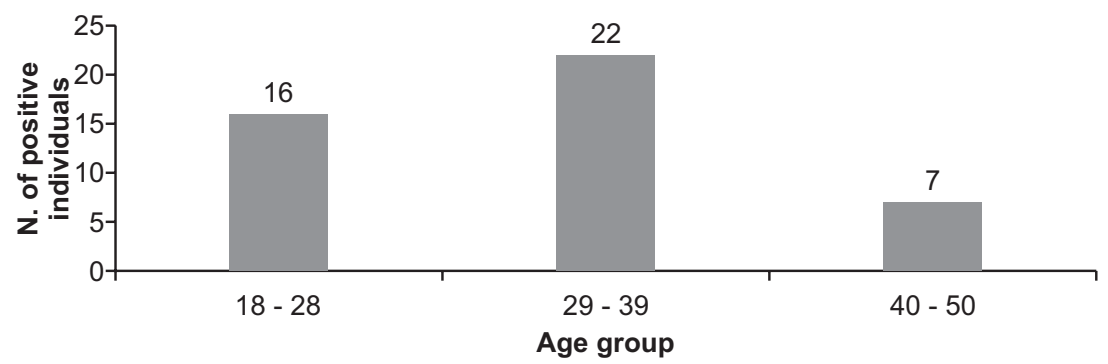

Figure 2. Schistosoma mansoni distribution by age of sugarcane cutting workers in northern Espírito Santo, Brazil, 2011.

\section{DISCUSSION}

The use of two parasitological techniques (spontaneous sedimentation and Kato-Katz) allows for much more accurate results, as described by some authors $(4,17)$, who reported that the laboratory routine should use more than one parasitological method for detecting parasitic forms of protozoa and helminths, especially in samples with low parasite load $(7,28)$. In this regard, when evaluating workers who participated in this study, it was observed that of all $45(15.68 \%)$ individuals positive for $S$. mansoni, 15 were identified by the spontaneous sedimentation technique, whereas the Kato-Katz method allowed for the identification of 42 positives. The positivity rate $(15.7 \%)$ in Conceição da Barra, despite representing the rate of infection of workers from endemic areas for schistosomiasis, is greater than values found in Brazilian states with a high incidence of schistosomiasis, as observed by the "Programa de Controle da Esquistossomose" (PCE) in Alagoas, one of the Brazilian states with the highest incidence of the disease, which showed that $9.9 \%$ of the population in the last 13 years was infected by the parasite (27). There is also the presence of infected workers originating from the states of Pernambuco and Bahia, regions historically with high prevalence of schistosomiasis $(20,27)$.

The high infection rate, the inadequate housing, since they live in dormitories inside the plant, the access to water collections in their leisure time and the presence of intermediate mollusk hosts $(3,31)$ are extremely important factors in the epidemiology of the disease, considering that a survey conducted in 41 localities from seven municipalities in northern Espírito Santo, including Conceição da Barra, showed the presence of thousands of mollusk of species Biomphalaria glabrata and $B$. straminea (31). Although none of the mollusks were positive for $S$. mansoni (31) the presence of infected individuals in the region may favor the spread of the disease, especially when considering that 72 municipalities in the state of Alagoas compose the so-called region of high risk of schistosomiasis (6) and that most positive sugarcane cutters came from that state. 
In this sense, it is also important to consider that a significant proportion of these workers take up residence in the municipality of Conceição da Barra, since after the sugar cane season, they are recruited for coffee collection.

Thus, the seasonal migration of these workers to the state of Espírito Santo, especially to the northern region, historically non endemic $(19,27)$, the poor sanitation in rural and urban areas, especially in places where workers reside, may represent the onset of the formation of new foci of schistosomiasis transmission, which is already endemic in 47 of the 78 municipalities in the state of Espírito Santo (26).

Regarding the age of workers who participated in the study, which ranged from 18 to 59 years, those aged between 29 and 39 years showed the highest number of infected individuals. The greater occurrence of parasitized individuals in this age group, which results in a decrease of their production capacity (15) is probably due to the cultural habit of that population, directly related to their leisure activities such as swimming, fishing and sports in water collections near to where they live $(9,23)$.

Once the number of infected individuals was established, the number of $S$. mansoni eggs per gram of feces per individual was determined, with values ranging from 24 to $864 \mathrm{epg}$. From all infected individuals, 32 had low parasite load (up to $100 \mathrm{epg}), 8$ had intermediate parasite load ( $>100$ and $<400 \mathrm{epg}$ ) and 2 had high parasite load (above 400 epg).

It is noteworthy that the higher or lower morbidity of schistosomiasis depends largely on the individual's parasite load $(22,34)$ whose quantification allows the evaluation of the effectiveness of prophylactic and disease control measures (16). Accordingly, special attention is needed to the two workers, both above 40 years, who had high parasite load. Despite the cultural habits of younger individuals that make them more susceptible to contamination (31), the finding of two individuals with high parasite load $(\mathrm{p}<0.05)$ is of importance since they contribute significantly to the transmission process of schistosomiasis.

In addition, the poor health care conditions and poor sanitation conditions contribute to the onset of the disease in the municipality of Conceição da Barra. Thus, in conclusion, the proper treatment of infected individuals, given the low cost of drug therapy (8) and measures to promote health and education, directed both to its population and to migrant workers, especially sugarcane cutters, should be implemented in order to avoid the introduction of this important parasitic disease in northern Espírito Santo.

\section{ACKNOWLEDGMENTS}

To the technicians of the National Health Foundation (FNS) João Afonso and Luiz do Rosário for their contribution in field work. To Nurse Maria Estevão, State Health Superintendent of São Mateus, ES, for her technical assistance in analyzing the material. 


\section{REFERENCES}

1. Amaral RS, Tauil PL, Lima DD, Engels D. An analysis of the impact of the Schistosomiasis Control Programme in Brazil. Mem Inst Oswaldo Cruz 101: 79-85, 2006.

2. Barbosa CS, Pieri OS, Silva CB, Barbosa FS. Ecoepidemiologia da esquistossomose urbana na ilha de Itamaracá, Estado de Pernambuco. Rev Saude Publica 34: 337-341, 2000.

3. Bezerra FSM. Moluscos transmissores do Schistosoma mansoni. In: Neves DP, Melo AL, Genaro O, Linardi PM. Parasitologia Humana. Atheneu, São Paulo, 2005.

4. Carvalho GLX, Moreira LE, Pena JL, Marinho CC, Bahia MT, Machado-Coelho GLL. A comparative study of the TF-Test ${ }^{\circledR}$, Kato-Katz, Hoffman-Pons-Janer, Willis and Baermann-Moraes coprologic methods for the detection of human parasitosis. Mem Inst Oswaldo Cruz 107: 80-84, 2012.

5. Conceição MJ, Coura JR. Epidemiology of Schistosomiasis mansoni in Brazil. In: Rokni MB. Schistosomiasis. InTech, Rijeka, 2012.

6. Couto JLA. Esquistossomose mansoni em duas mesorregiões do Estado de Alagoas. Rev Soc Bras Med Trop 38: 301-304, 2005.

7. Enk MJ, Lima AC, Drummond SC, Schall VT, Coelho PM. The effect of the number of stool samples on the observed prevalence and the infection intensity with Schistosoma mansoni among a population in an area of low transmission. Acta Trop 108: 222-228, 2008.

8. Gabrielli, AF, Montresor A, Chitsulo L, Engels D, Savioli S. Preventive chemotherapy in human helminthiasis: theoretical and operational aspects. Trans R Soc Trop Med Hyg 105: 683-693, 2011.

9. Guimarâes ICS, Tavares-Neto J. Transmissão urbana de esquistossomose em crianças de um bairro de Salvador, Bahia. Rev Soc Bras Med Trop 39: 451-455, 2006.

10. Hoffmann WA, Pons JA, Janer JL. Sedimentation concentration method in schistosomiasis mansoni. J Publ Hlth 9: 281-298, 1934.

11. IBGE. Instituto Brasileiro de Geografia e Estatística. Informações Estatísticas. Brasil, 2010. Available from: http://www.ibge.gov.br/cidadesat/topwindow.htm? Accessed in 10/02/2013.

12. Katz N, Almeida K. Esquistossomose, Xistosa, Barriga D’Água. Cienc Cult 55: 38-43, 2003.

13. Katz N, Peixoto SV. Análise crítica da estimativa do número de portadores de esquistossomose mansônica no Brasil. Rev Soc Bras Med Trop 33: 303-308, 2000.

14. Katz N, Chaves A, Pellegrino J. A simple device for quantitative stool thick- smear technique in schistosomiasis control. Rev Inst Med Trop Sao Paulo 14: 397-402, 1972.

15. King, CH. Parasites and poverty: The case of schistosomiasis. Acta Tropica 113: 95-104, 2010.

16. Melo AL, Coelho PMZ. Schistosoma mansoni e a doença. In: Neves DP, Melo AL, Genaro O, Linardi PM. Parasitologia Humana. Atheneu, São Paulo, 2005.

17. Mendes CR, Teixeira ATLS, Pereira RAT, Dias LCS. Estudo comparativo de técnicas parasitológicas: Kato-Katz e coprotest ${ }^{\circledR}$. Rev Soc Bras Med Trop 38: 178-180, 2005.

18. Neves RH, Machado-Silva JR, Pelajo-Machado M, Oliveira SA, Coutinho EM, Lenzi HL, Gomes DC. Morphological aspects of Schistosoma mansoni adult worms isolated from nourished and undernourished mice: a comparative analysis by confocal laser scanning microscopy. Mem Inst Oswaldo Cruz 96: 1013-1016, 2001.

19. Paraense WL, Aires de Alencar JT, Corrêa LR. Distribuição de planorbídeos e prevalência da xistosomose mansoni no Estado do Espírito Santo. Mem Inst Oswaldo Cruz 78: 373-384, 1983.

20. Pordeus LC, Aguiar LR, Quinino LRM, Barbosa CS. A ocorrência das formas aguda e crônica da esquistossomose mansônica no Brasil no período de 1997 a 2006: uma revisão de literatura. Epidemiol Serv Saude 17: 163-175, 2008.

21. Quinino LRM, Costa JMBS, Aguiar LR, Wanderley TNG, Barbosa CS. Avaliação das atividades de rotina do Programa de Controle da Esquistossomose em municípios da região metropolitana do Recife, Pernambuco, entre 2003 e 2005. Epidemiol Serv Saude 18: 335-343, 2009.

22. Rey L. Esquistossomíase Mansônica: A Doença e Epidemiologia e Controle da Esquistosomíase nas Américas. In: Rey L. Bases da Parasitologia Médica. Guanabara Koogan, Rio de Janeiro, 2010. 
23. Rollemberg CVV, Santos CMB, Silva MMBL, Souza AMB, Silva AM, Almeida JAP, Almeida RP, Jesus AR. Aspectos epidemiológicos e distribuição geográfica da esquistossomose e geo-helmintos, no Estado de Sergipe, de acordo com os dados do Programa de Controle da Esquistossomose. Rev Soc Bras Med Trop 44: 91-96, 2011.

24. Secretaria de Vigilância em Saúde, Ministério da Saúde. Departamento de Vigilância Epidemiológica. Doenças Infecciosas e Parasitárias: guia de bolso. Brasília: Ministério da Saúde; 2004. Available from: http://bvsms.saude.gov.br/bvs/publicacoes/guia_bolso_4ed.pdf. Accessed in $15 / 01 / 2013$.

25. Secretaria de Vigilância em Saúde, Ministério da Saúde. Departamento de Vigilância Epidemiológica. Guia de Vigilância Epidemiológica. Brasília: Ministério da Saúde; 2009. Available from: http://portal.saude.gov.br/portal/arquivos/pdf/gve_7ed_web_atual.pdf. Accessed in $15 / 01 / 2013$.

26. Secretaria de Vigilância em Saúde, Ministério da Saúde. Sistema Nacional de Vigilância em Saúde. Relatório de Situação: Espírito Santo. Brasília: Ministério da Saúde; 2011. Available from: http:// bvsms.saude.gov.br/bvs/publi- cacoes/sistema_nacional_vigilancia_saude_es_5ed.pdf. Accessed in $15 / 01 / 2013$.

27. Secretaria de Vigilância Epidemiológica, Ministério da Saúde. Programa de Controle da Esquistossomose. Brasília: Ministério da Saúde; 2012. Available from: http:/tabnet.datasus.gov.br/ cgi/tabcgi.exe?sinan/pce/cnv/pce.def. Accessed in 15/01/2013.

28. Siqueira LMV, Coelho PMZ, Oliveira AA, Massara CL, Carneiro NFF, Lima ACL, Enk MJ. Evaluation of two coproscopic techniques for the diagnosis of schistosomiasis in a low-transmission area in the state of Minas Gerais, Brazil. Mem Inst Oswaldo Cruz 106: 844-850, 2011.

29. Sousa MRC. Esquistossomose no Brasil: ensinar versus educar. RBEM 33: 144-147, 2009.

30. Souza MAA, Barbosa VS, Albuquerque JO, Bocanegra S, Souza-Santos R, Paredes H, Barbosa CS. Aspectos ecológicos e levantamento malacológico para identificação de áreas de risco para transmissão da esquistossomose mansoni no litoral norte de Pernambuco, Brasil. Iheringia Sér Zool 100: 19-24, 2010.

31. Souza MAA, Melo AL. Ecological Aspects of Biomphalaria in Endemic Areas for Schistosomiasis in Brazil. In: Rokni MB. Schistosomiasis. InTech, Rijeka, 2012.

32. Tao J, Peng HK, Cai WM, Dong FQ, Weng HL, Liu RH. Influence factors of serum fibrosis markers in liver fibrosis. World J Gastroenterol 9: 2497-2500, 2003.

33. Uecker M, Copetti CE, Poleze L, Flores V. Infecções parasitárias: diagnóstico imunológico de enteroparasitoses. RBAC 39: 15-19, 2007.

34. World Health Organization. The Control of Schistosomiasis. Technical Report Series $N^{\circ} 728$. WHO, Geneva. 